\title{
Accountability of the performance of general election of the regional head supervisory committee in 2015 of Gorontalo District
}

\author{
$1^{\text {st }}$ Rusly Abdurahaman Idji \\ Public Administration \\ Universitas Negeri Makassar \\ Makassar, Indonesia \\ ruslyabdurrahman@gmail.com
}

\author{
$2^{\text {nd }}$ Husain Syam \\ Public Administration \\ Universitas Negeri Makassar Makassar, \\ Indonesia
}

\author{
$3^{\text {rd }}$ Fakhri Kahar \\ Public Administration \\ Universitas Negeri Makassar Makassar, \\ Indonesia
}

\begin{abstract}
The low trust of the majority of the community towards the independent institutions of the General Election of the Regional Head threatens the growth of democratic governance. This study aims to describe and analyze the performance accountability of the Election Supervisory Committee of 2015 in Gorontalo District. The main data was collected through in-depth interviews, observation, and documentation. The results of the research showed that the preventive action against infringement of Pemilukada in 2015, was quite prone to index 2.28. From 5 indicators used, 2 indicators were considered vulnerable namely, money politics with the value of index 3.5 and public participation with the value index3, 3. Panwaslukada has claimed to have been transparent in surveillance, although some of the society still have doubts. The commoners who are categorized as the poor have always been subjected to the vulnerability of participation and money politics in elections in 2015, because of the many stakeholders from holding parties to successful teams. However, violations occurring during the implementation of the General Election were materially unproven.
\end{abstract}

Keywords- Prevention, Action, Dispute Resolution, Panwaslu Accountability, Year 2015

\section{INTRODUCTION}

The General Election of Regional Head or Pemilukada directly constitutes the means of the implementation of the sovereignty of the people to channel political aspirations directly, publicly, freely, secretly, honestly and fairly in the Unitary State of the Republic of Indonesia based on Pancasila and the 1945 Constitution of the Republic of Indonesia, to bring democratic governance into account. To guarantee the implementation of direct, general, free, confidential, honest, and fair elections. requires the institution of independent and autonomous oversight. This institution was established to strengthen the pillars of democracy, minimize the fraud in the elections as the core of forming a characterized government [1]-[4]. The main features of independent electoral supervision are: (1) constituted by constitutional order or law, (2) not easily intervened by certain political interests, (3) accountable to parliament, (4) performing tasks in accordance with the stages Pilkada, (5) has good integrity and morality and, (6) understands the procedures for the implementation of Pilkada.
Independent institution in question is the Elections Supervisory Agency or Bawaslu at the central and provincial levels, as well as the Election Supervisory Committee or Panwaslu and the Regional Head Election at district/city level. The establishment based on the Law number 15 of 2015, as a replacement Law Number 22 Year 2007, concerning the Organizer of the General Election. The institution, as the organizer of General Election of Regional Head that is independent and free from co-optation of the authorities, charged with overseeing the election organizers and General Election in Indonesia. Supervision is focused on three main issues concerning the prevention, prosecution, and dispute resolution. Prevention and prosecution shall take place in the event of a violation of the updating of voter data, candidacy, the process of determination, determination, implementation of the campaign, the execution of voting and vote counting. Additionally, supervision of the performed oversight throughout the counting process, the movement of ballot papers from the polling station level to the PKK, the process of recapitulation of votes by Regency/City from all districts, implementation of the calculation and re-votes, advance election, and continuation election, and the approval process of the election results of the members of provincial and municipal council member and the election of regent/ mayor [5]-[8].

As an institution that uses the state budget in carrying out its duties and authorities, Bawaslu and Panwaslukada are required to maintain a system of openness, accountability, and accountability. It was also emphasized by [9], that "the implementation of elections should be carried out by promoting the principles of accountability, in which includes the aspects of transparency and participation". Theoretically, election supervisors are a state agency tasked with ensuring accountability. According to [10] accountability as the relationship between the parties in control and governing the entity with the party having formal power over the controlling party. In the context of governance, government accountability cannot be known without the government informing the people of information regarding the collection of resources and other sources of society and their use.

In an effort to fulfill the needs of life, a member of Panwaslukada tried to work well in accordance with the 
provisions outlined. On the other hand, the participants of Pemilukada (candidates for Regent/Vice Regent) and the successful team, tried various ways to influence the organizers of Pemilukada to help them win the election. The Supervisory Committee in a vulnerable position, raising questions about how the accountability of the performance of the tasks assigned to them. Although the Supervisory Committee members have qualified from the election results are quite heavy, about the capability and high expertise in translating duties and powers relating to the implementation of the General Election, has integrity, a strong, honest, and fair person, enforce by his/her willingness to work full-time, but not a guarantee, that they can be accountable for its performance in accordance with applicable regulations.

The Result of in district of Jembrana Bali showed, that the Supervisory Committee's role in the implementation of the General Election didn't work optimally because it has not been given the broad role, and still as an ad hoc institution, and recruitment patterns that have not been good. Similarly, the results of the study in North Moskona District of Bintuni Bay Regency of West Papua province indicate that Panwas has not maintained neutrality and performs its functions well in accordance to the provisions. Sidik's research results (2016), in Province of Lampung, indicated that a lack of human resource capacity of the Election Supervisor at Regional/City Election Supervisory ranks below to understand and carry out their duties and functions.

There are a still widespread violation and fraud contradictory premises $\mathrm{n}$ regulations and occurred before and during the implementation of the General Election, showed a lack of oversight. According to [11], General Election and Regional Head General Election could proceed democratically if there is supervision carried out openly honest and fair by Bawaslu at Central and Provincial levels, and Panwaslu at the District/City level. In this study, the problems are focused on performance accountability Election Supervisory Committee (Panwaslukada) Gorontalo Regency in 2015 which accounted for about a performance plan that has been set in terms of prevention of violation, violation enforcement, and dispute resolution and promoting transparency and participation in order to improve the quality of task implementation.

Based on the observations, lack of public trust to the Election Organizers in Gorontalo Regency 2015, so that accountability performance of Election Supervisory Committee in Gorontalo district was questioned. On the other hand, level of percentage of total stakeholder involvement in the supervision of the election, still confined to political elites who have an interest in fighting for the candidate. The task of overseeing the election in the field, more dominantly implemented by District Supervisory Committee and Election Supervisory Committee (PPL), and supervision at the polling station (TPS). The degree of violation has not been significantly reduced, especially in cases of unregistered voters, multiple names, deceased voters, including registered voters but not yet eligible voters, and PPS who did not make Temporary Voters List announcement. In addition, different interests that still interferes with the Supervisory Committee in carrying out its functions. This has led to many public demands for the low prevention of violations, the violation and dispute resolution of Pilkada, which triggered the protests as an act of public discontent. Within that framework, through the review of the performance accountability of Panwaslukada Gorontalo Regency in 2015, the researcher identified the duties of prevention, scrutiny and dispute resolution..

\section{RESEARCH METHOD}

This case study research used various data sources to achieve the validity and reliability of the data in revealing the facts behind the case studied. The objective was to obtain an analytical description of the accountability performance of Supervisory Committee's performance in the implementation stage of Gorontalo regency election in 2015. The data obtained, either in the secondary or the primary data, were compiled and analyzed qualitatively in accordance with the perceived problems. Collecting data was done in the form of documents, records, observation, open interviews, the interview focused, structured interviews and field surveys, its principal matters related to oversight of the election in Gorontalo Regency in 2015. The context of the observation of the process of the General Election of Regional Heads is expected to understand more fully in relation to the issues to be analyzed further. Through observation, it was expected that any unsuccessful material may be obtained relied on formal data or information. The result of observation will be deepened by doing an in-depth interview. The in-depth interview focused, structured on informants based on prepared interview guides. The result obtained through this data collection techniques then analyzed descriptively. The informant obtained through a purposive technique that is a sample determination technique for certain purpose only [12]. Informants as primary data source consisted of Gorontalo Regency, Supervisory Committee of Gorontalo Regency, District Supervisory Committee, Kesbangpol Gorontalo Regency, Coordinator of TPD-DKPP Province of Gorontalo, KDP, Successful Team and local community leaders.

\section{RESULT AND DISCUSSION}

\section{A. Accountability of Violation Prevention Performance}

Preventive action as one of the ways that must be done by Panwaslukada Gorontalo Regency, in order to minimize the occurrence of violations based on the transparent laws and regulations as contained in Article 77 Paragraphs (1) and (2), and Article 78 of Law Number 15 of 2011, concerning General Election Organizer. There is 12 (twelve) point of duties and authority of Panwaslu, in conducting supervision on the implementation of Pemilukada. From the 12 (twelve) points, this study only focused on 5 (five) points that were considered vulnerable in the implementation of Gorontalo Regency Election 2015, namely: at the stage of nomination process, stages of determination of candidate pair of Gorontalo Regional Head , stages of voting and counting, stages of stipulation of elected candidate pairs ( dispute settlement of elected candidate after the Constitutional Court decision and proposal for approval of appointment of elected candidate pair). In the nomination supervision process was based on the General Elections Supervisory Board (PERBAWASLU) of the Republic of Indonesia Number 5 of 2015 on the Control of Election Nominations Stages of Governor and 
Vice Governor, Regent and Vice Regent and the Mayor and Deputy Mayor. Every act of Panwaslukada Gorontalo Regency in preventing the nomination process was always coordinated with Gorontalo Regency KPU by looking at all the evidence submitted by prospective candidates in fulfilling the requirements and requirements of the candidate as much as 20 (twenty) items at the time of registration.

The twenty requirements submitted by the candidates of Regent and Deputy Regent to Gorontalo Regency Election Commission at the time of registration were examined one by one by Panwaslukada Gorontalo. The study focused on the attachment of administrative evidence and after analyzing there was still lack of requirement proposed by individual candidate pair by Panwaslukada in cooperation with Bawaslu Gorontalo Province, assisted by District Election Supervisory Committee (PPK) related to candidate residence. Panwaslukada Kabupaten Gorontalo has ensured that the KPU conveys publicly to the registration of candidates and candidate requirements.

Prevention of the nomination process is done by observing whether the nomination stage is in accordance with the provisions and is transparently known by the general public. The performance of Panwaslukada Gorontalo Regency in the prevention of the nomination process has been demonstrated in the absence of problems found in the nomination stage. The winning team of candidates and the general public were not objected. Regency KPU Gorontalo has previously socialized and announced the terms and conditions of support of candidate pairs either promoted by political parties or individual candidate pairs. All candidacy requirements and their attachments have been studied to cover the completeness and validity of nomination administration, and have been clarified to the authorized institution.

All actions, facts, and activities that have been implemented by Panwaslukada Gorontalo Regency were in order to apply the governance approach termed by Kooiman (1993: 21) with "governance" that is "the act, fact, a manner of governing". That is, the implementation of Gorontalo Regency Election is based on actions, facts, and activities (process), more of a "..... a series of processes of sociopolitical interaction between government and society in various fields related to public interest and government intervention on those interests. In regard to the nomination process, the task of Panwaslukada is closely related to the psychological condition of the community which views that the independent KPU can be trusted. Therefore, supervision of every stage in the process of nomination of Panwaslukada Gorontalo Regency can guarantee and minimize the violation either in administrative form concerning the requirement of the candidate or in technical form at the nomination stage.

Similarly, in the process of stages of determination of candidate pairs, prevention is done by examining the conditions that have been proposed and found there were still improvements in candidacy requirements. Since the registration of candidate pairs, the submission of candidate requirements and requirements to the medical examination, and the submission of the results of the medical examination, no violation has been found on the determination of the candidate pair. Except in the prospective candidate, there is still a lack of support requirements requested for improvement until the time limit before the date of the stipulation of the nominated candidate. The opportunity to provide an opportunity for individual candidate pairs to improve the terms of support in accordance with the provisions, indicates that the organization of KPU Gorontalo Regency and Panwaslukada Gorontalo Regency, embraces the paradigm of citizenship values in organizational activities as expressed by Solow, namely strengthening existing norms and social values, then encouraging the willingness of community members to be active, serving each other, including being a street-level leadership figure.

Prevention on the implementation of the campaign stages is one of the most potential violation activities. 7 Year 2015, Regarding Campaign for Election of Regional Head, the implementation of the campaign was conducted from August 27, 2015, until December 05, 2015, after the drew of the candidate pair number. Monitoring of this campaign activity was susceptible to infringement of props and others. In supervising the implementation of the campaign included observing the participants of the campaign, reviewing, reviewing and assessing the process of organizing the campaign and the activities of the candidate and winning team participants, to convince voters by offering vision, mission, and election program. Generally, a violation occurs in the creation of a campaign report that is less credible funds not based on accounting standards that will provide information to the public how the political parties get the funds, the skills to manage the funds, and orderly spending. Panwaslu was difficulty proving the use of fictitious or illegal campaign funds. Panwaslukada Gorontalo Regency sometimes has to turn a blind eye to the possibility of complicated problems especially related to campaign funding, because of the difficulty of tracing in addition to the lack of operational fund oversight of the implementation of elections thereby reducing the seriousness in running their function. The result of the study of the Indonesian Auditor Association (IAI: 2009), on the use of campaign funds of Pemilukada, the obstacles faced in the field were the administration of campaign reports campaigns was not good and not all recorded, the campaign fund audit time was very limited and only for 15 days, so that gap between public expectation and the results of the audit was too large. Prevention of the voting and counting by Panwaslukada was in association with the prevention violations manipulating count of votes and at the time of recapitulation. In the election of Regent and Vice Regent of Gorontalo Regency in 2015 , the case of vote manipulation and recapitulation of vote count result is very minimal violation done at the level of village/sub-district voting committee to sub-district and district level. There was no difference voting result per late with the calculation results at the polling stations. The recapitulation of the voting result was done transparently involving all parties starting from PPS level, then taken to KDP level (district selection committee) accompanied by field supervisor to be recapitulated by the District Selection Committee ( PPK ) to then proceed to the District KPU Gorontalo. The activity according to [13], is a consequence of the determination transparency as one of the principles of good governance which today can be regarded as a dead price to be done government. In addition, transparency or openness was the demands of the development of good governance paradigm and the development of democratization also because of critical awareness of the 
community that has begun to flourish. The realization of good governance requires openness, involvement, and ease of access for the community towards the implementation process of a policy, especially in the implementation of democratic parties and in the use of various resources directly related to the public interest.

Prevention is focused on the mechanisms and procedures set out in Commission Regulation No. 12 of 2015 on the Amendment of the General Elections Commission Regulation No. 9 of 2015 On Election Nomination of Governor and Deputy Governor, the Regent and Vice Regent, and/or the Mayor and Deputy Mayors. In the implementation of the determination of the elected candidates, no violations or reports were received by Panwaslu Gorontalo Regency, either submitted by the winning team of other candidate pairs or from the community members until the issuance of a decision on the determination of the elected candidate by the Gorontalo Regency Election Commission. If this condition maintained, The results can be seen from a functional spec from the government that is effective and efficient in the implementation of tasks to achieve the goal. Based on the description, no violation has been found that resulted in sanctions or criminal actions since of the nomination process, the determination of candidate pairs, voting and vote counting, and the determination of elected candidate pairs, except in the stages implementation the campaign that has not been transparent reported the use of campaign funds. The ad hoc Panwaslukada status makes individuals performing duties and functions have no external means of structural power down to the lower levels (sub-districts and villages) and are limited by internal norms that their duties and functions only record violations receive reports and recommend authorizing. However, as the overall performance of Panwaslukada Gorontalo Regency was accountable for conducting preventive action violation on each stage of the implementation of General Election of Regional Head.

\section{B. Performance Accountability of Violence Act}

The act of violation in the election of Regent and Vice Regent of Gorontalo 2015, conducted by Panwaslukada Gorontalo Regency if found or there were reports of the community occurrence of violation at every stage. As described in the section above, on the prevention of violation since stage nomination process, determination of candidate pair, and vote counting, and the determination of selected candidate pairs has not been found to be sanctioned, whether administrative, criminal or ethical. Another thing except for the implementation of the campaign relating to financial management that was not transparently reported the use of campaign funds.

The violation of non- fulfillment of support requirements for individual candidates in accordance to the Regulation of the General Elections Commission (KPU) Number 9 in 2015, on the Candidate of Governor and Deputy Governor, Regent and Vice Regent, and/or Mayor and Vice Mayor shall be deemed not to be a non- can be sanctioned because there is still time to improve the number of support requirements in accordance with the provisions. Of the 5 (five) candidates for Regent/Vice Regent of Gorontalo Regency in 2015, there was 3 (three) candidate pairs that get support from political parties. All five (5) candidates are, always be cautious because of the intense competition the vote. Each pair of aspiring and enthusiastic winning teams will have a great chance and opportunity to gain a vote and not feel worried about the threats of individual prospective pairs.

Every election and election, voters are always in trouble, causing multiple voters. Multiple voters stayed in more than one place, and when fixed on the permanent voters list they leave their residence. There were some people also who have not registered as permanent voters, but on the voting day of the voting population was in the voting location. That is why most of the Potential Voters List ( DP4) in Gorontalo District cannot be relied upon as candidates for permanent voters. Based on the data, there were public reports of violations in the nomination process. However, after being traced and verified in a transparent manner by members of Panwaslukada directly in coordination with Gorontalo Regency Election Commission, in cooperation with District Supervisory Committee and Field Supervisory Committee, the violation is related to the submission of unaudited candidate support requirement in the form of photocopy of the identity of the identity which is doubtful of its authenticity. Panwaslukada immediately took action against any findings and reports from the public and took action up according to the authority that is recorded violations, receive reports and recommend to the competent institution. The Performance of Panwaslukada of Gorontalo Regency in conducting the prosecution for violation of Gorontalo Regency Election 2015, starting from the stages of the nomination process, determination of candidate pair, campaign, voting and vote counting, until the determination of elected candidate pair was considered accountable.

The four main elements or principles that must be emphasized with the first emphasis on accountability that is, in addition to the obligation of all actions and policies established, the principle of accountability must be done transparently to the people, from top to bottom level with the principle of "openness". The people should be given the widest opportunity to submit a response and criticism of what the state organizers do if they are not transparent. From several stages of General Election of Regional Head, the execution of voting and counting is the peak of vulnerability that can lead to conflict. Therefore, the superintendents, especially the field election supervisors and the District Supervisory Committee are more cautious in observing the implementation of voting starting at polling stations, at the Village level by the Voting Committee and by the Voting Organizing Group. The classical problem in every vote was the lack of accurate voter data when it is fixed as a permanent voter list or when approaching polling day. Although the main issues that often become the root of the problem is the difference in understanding of the rules of the game or the rule of the game in the election, but the main thing that always watch out is the problem of mentality of election organizers, election participants, as well as other elements that perform acts that can injure democracy. Because, the task that is quite heavy in the implementation of the General Election is at the time of voting and vote counting, so intensively conducted coordination with all parties involved in the implementation of the General Election of Gorontalo Regency and especially involving the voting community. Supervisors always evaluate each stage of voting and counting and immediately take action when 
there are suspicious matters including findings and reports. According to Amirudin and Bisri (2006), there is still a perception of the general public that direct elections are often interpreted as opportunities for - for money. Therefore, the organizers of Pemilukada worked in accordance with the prevailing provisions and always behave well by didn't violate the code of ethics. The organizers of the election of the Regent and Vice Regent of Gorontalo Regency, especially Panwaslukada Gorontalo Regency, always obey what is forbidden, and carry out what is proper or not worth doing in all actions and his speech. This condition makes the performance of Panwaslukada Gorontalo Regency, in every stage of the implementation of the Election of Regional Heads of Gorontalo Regency, was considered accountable.

\section{Performance Accountability for Dispute Resolution}

In Law No. 8 of 2015, on Amendment to Law No. 1 of 2015, Concerning the Stipulation of Government Regulation in Lieu of Law No. 1 of 2014, on the Election of Governors, Regents and Mayors into Law, Section 142, it is said that that the election dispute consists of (a) the dispute among the election participants; and (b) disputes between election participants and election organizers as a result of the issuance of KPU Provincial and Regency/City KPU Decisions. Under the regulation, the performance of Panwaslukada Gorontalo was related to the settlement of the two types of disputes in question. While dispute resolution procedures were regulated in the Election Supervisory Agency Regulations General or Perbawaslu Number 8 Year 2015, Concerning the Method of Settlement of Election of Governor and Deputy Governor, Election of Regent and Vice Regent, and Mayor and Deputy Mayor. Panwaslukada Gorontalo Regency performance on overall responsibility for an appropriate provision, transparent, efficient and effective, and responsive emphasizes honesty and laws, processes, programs and policies in the settlement of disputes General Election of Regent and Vice Regent of Gorontalo. As is has been described in the sections above, the violations found as well as the reports of the community, have been researched, reviewed and analyzed, the findings and reports have been well resolved. Panwaslukada has responded transparently to every reported case relating to the election of the Regent and Vice Regent of Gorontalo Regency. The list of violations that have been finished is described in the following table 1.

TABLE 1. LIST OF VIOLATION REPORTS

\begin{tabular}{|c|c|c|c|}
\hline $\begin{array}{c}\text { Num } \\
\text { ber }\end{array}$ & $\begin{array}{c}\text { Number and Date } \\
\text { of findings }\end{array}$ & Stages & Report \\
\hline 1 & $\begin{array}{l}002 \text { / LP / XII / } 2015 \\
\text { Date. 06 Dec } 2015\end{array}$ & $\begin{array}{c}\text { Quiet } \\
\text { period }\end{array}$ & $\begin{array}{l}\text { Passed on to the Regent of } \\
\text { Gorontalo }\end{array}$ \\
\hline 2 & $\begin{array}{l}\text { 003 / LP / XII / } 2015 \\
\text { Date. 07 Dec } 2015\end{array}$ & $\begin{array}{c}\text { Quiet } \\
\text { period }\end{array}$ & $\begin{array}{l}\text { Followed up and forwarded to } \\
\text { related parties (Gorontalo } \\
\text { Police Resort \& KPU } \\
\text { Gorontalo }\end{array}$ \\
\hline 3 & $\begin{array}{l}004 \text { / LP / XII / } 2015 \\
\text { Date. 08 Dec } 2015\end{array}$ & $\begin{array}{c}\text { Quiet } \\
\text { period }\end{array}$ & $\begin{array}{l}\text { Followed up to related parties } \\
\text { Police investigators }\end{array}$ \\
\hline 4 & $\begin{array}{l}005 \text { / LP / XII / } 2015 \\
\text { Date. Dec 09 } 2015 \\
\end{array}$ & $\begin{array}{l}\text { Quiet } \\
\text { period }\end{array}$ & $\begin{array}{lll}\begin{array}{l}\text { Handling } \\
\text { stopped }\end{array} & \text { Infringement is } \\
\end{array}$ \\
\hline 5 & $\begin{array}{l}006 \text { / LP / XII / } 2015 \\
\text { Date. Dec 10, } 2015\end{array}$ & $\begin{array}{l}\text { Quiet } \\
\text { period }\end{array}$ & Handling stopped \\
\hline 6 & $\begin{array}{l}007 \text { / LP / XII / } 2015 \\
\text { Date. Dec 10, } 2015\end{array}$ & $\begin{array}{l}\text { Quiet } \\
\text { period }\end{array}$ & $\begin{array}{lll}\begin{array}{l}\text { Suspicious handling of } \\
\text { suspected violation }\end{array} & \text { a } \\
\end{array}$ \\
\hline 7 & $\begin{array}{l}008 \text { / LP / XII / } 2015 \\
\text { Date. Dec. } 112015\end{array}$ & $\begin{array}{l}\text { Quiet } \\
\text { period }\end{array}$ & $\begin{array}{l}\text { Suspicious handling of a } \\
\text { suspected violation }\end{array}$ \\
\hline 8 & $\begin{array}{l}009 \text { / LP / XII / } 2015 \\
\text { Date Dec. } 112015\end{array}$ & $\begin{array}{c}\text { Quiet } \\
\text { period }\end{array}$ & $\begin{array}{l}\text { Discontinued/ } \\
\text { Not forwarded }\end{array}$ \\
\hline
\end{tabular}

\begin{tabular}{|c|c|c|c|}
\hline 9 & $\begin{array}{l}010 / \text { LP / XII / } 2015 \\
\text { December 11, } 2015\end{array}$ & $\begin{array}{l}\text { Quiet } \\
\text { period }\end{array}$ & $\begin{array}{l}\begin{array}{l}\text { Suspicious handling of a } \\
\text { suspected violation }\end{array} \\
\end{array}$ \\
\hline 10 & $\begin{array}{l}011 / \text { LP / XII / } 2015 \\
\text { December 11, } 2015 \\
\end{array}$ & $\begin{array}{l}\text { Quiet } \\
\text { period }\end{array}$ & $\begin{array}{l}\text { Handling alleged } \\
\text { infringement terminated }\end{array}$ \\
\hline 11 & $\begin{array}{l}012 \text { / LP / XII / } 2015 \\
\text { December 11, } 2015\end{array}$ & $\begin{array}{l}\text { Quiet } \\
\text { period }\end{array}$ & $\begin{array}{l}\text { Discontinued/ } \\
\text { Not forwarded }\end{array}$ \\
\hline 12 & $\begin{array}{l}013 \text { / LP / XII / } 2015 \\
\text { December 12, } 2015\end{array}$ & $\begin{array}{c}\text { Voting and } \\
\text { Vote } \\
\text { Counting } \\
\end{array}$ & $\begin{array}{l}\text { Suspicious handling of a } \\
\text { suspected violation }\end{array}$ \\
\hline 13 & $\begin{array}{l}\text { 014 / LP / XII / } 2015 \\
\text { December 14, } 2015\end{array}$ & $\begin{array}{l}\text { Voting and } \\
\text { Vote } \\
\text { Counting }\end{array}$ & $\begin{array}{l}\text { Discontinued/ } \\
\text { Not forwarded }\end{array}$ \\
\hline 14 & $\begin{array}{l}\text { 014 / LP / XII / } 2015 \\
\text { December 15, } 2015\end{array}$ & $\begin{array}{l}\text { Voting and } \\
\text { Vote } \\
\text { Counting }\end{array}$ & $\begin{array}{l}\text { Discontinued/ } \\
\text { Not forwarded }\end{array}$ \\
\hline
\end{tabular}

Based on data in the table above, the completion of infringement findings/report of Election of Regent and Vice Regent of Gorontalo in 2015, has been recommended to the parties concerned by Panwaslukada Gorontalo district based on the urgency of the case filed. In the description, the column has been described the reasons for the termination or non-continuation of cases reported by the public over the implementation of Election Gorontalo Regency. Disputes between election participants and election organizers as a result of the issuance of the Decision of the Gorontalo Regency Election Commission which stipulates the candidate pair number 2 as the elected candidate. The settlement of the dispute by Panwaslukada of Gorontalo Regency was conducted in coordination to the Gorontalo Regency Election Commission to examine, review, and assess the issue of dispute and subsequently to the applicant to submit a legal settlement to the Constitutional Court or MK in order to obtain formal legality to obtain legal certainty.

In the case of violations occurring during the implementation of the General Election of Gorontalo Regency, the most reported by the community as described above shows the high participation of the voting community in every stage of the Pemilukada. According to the Voter Education Network for the People (JPPR, 2014), the quality of Pemilukada is measured from five aspects such as high voter participation with awareness and honesty in determining their choice with a sense of responsibility and non-coercion, in addition to the independent attitude of the organizers of Pemilukada (KPU, Bawaslu, and DKPP), the government. The involvement of the community at every stage of the election of the Regent and Deputy Regent is a mandate of Article 131 of Law Number 8 of 2015, regarding the Amendment of Law Number 1 of 2015, Concerning the Stipulation of Government Regulation in Lieu of Law No. 1 of 2014, Concerning the Election of Governor, Regent, and Mayor Become Act. The article mandates that to support the smooth conduct of elections, it may involve community participation. Such community involvement is in the form of supervision at every stage of the election, election socialization, political education for voters, surveys or voting polls, and quick counts of election results.

According to [14], the direct election of Pilkada is to provide wide space for the participation of the community polytheists to determine the regional heads according to their aspirations and needs in their respective regions so that the policies of the government are expected to be in line with the expectations and wishes of the people generally. 
According to the provisions stipulated in the Regulation of the Election Supervisory Board or KPU Number 8 of 2015, Concerning the Settlement of Election of Governor and Deputy Governor, Election of Regent and Vice Regent, and Mayor and Vice Mayor, the application for election dispute resolution shall be submitted within 3 (three) days since the disputed object was known and reported. In case of the application was submitted beyond the stipulated time period, Panwaslukada Gorontalo did not accept the petition filed.

Based on the description above, the findings of this study are sequenced according to the formulation of the problem as follows:

The main responsibility of supervising the election of Regent and Vice Regent of Gorontalo Regency in 2015 was the Supervisory Committee of Gorontalo. Responsibility must be established in a coordination mechanism and cooperation of stakeholders of General Election of Regional Head organizers and the public to improve interaction synergy in the prevention of violation activities, prosecution, and dispute resolution.

Coordination and partnership of stakeholders of General Election of Regional Head and community, depending on transparency, consistency, and honesty. Co-ordination of coordination and partnership among components of stakeholders and society was not optimal in terms of actualization of the principles of transparency, consistency and honesty behavior on the control of prevention of violations, violation, dispute settlement, resulting in the gap of interest and the phenomenon of egoism power.

Supervision of the election of Regents and Deputy Regents, depending on the role of coordination and cooperation of stakeholders in encouraging accountability of supervisory performance to improve supervisory in terms of prevention of violations, violations, and dispute settlement. In other words, the success of Panwaslukada Gorontalo in accounting for the performance of supervision depends on the coordination factor and cooperation of stakeholders and the community.

\section{CONCLUSION}

Based on the description of the research result and discussion about accountability of Panwaslukada performance of Gorontalo Regency, it was concluded as: 1) The performance of Panwaslukada Gorontalo in the prevention of violations in the implementation of the election of Regent and Vice Regent of Gorontalo Regency was considered accountable because it minimized the violations in the nomination process, a stipulation of candidate pairs, campaign implementation, voting and counting, and determination of selected candidate pairs by on transparent legislation., 2) The performance of Panwaslukada Gorontalo in the case of the act of violation in the implementation of the election of Regent and Vice Regent of Gorontalo Regency was considered accountable because it accounted for the task of violating the candidacy process, the determination of candidate pairs, campaign implementation, voting and vote counting, based on transparent legislation. 3) The performance of Panwaslukada Gorontalo in terms of settlement of dispute over violation in the implementation of the election of Regent and Vice Regent of Gorontalo Regency was considered accountable because it was responsible for the settlement of violation disputes in the nomination process, stipulation of candidate pairs, campaign implementation, voting and vote counting, elected candidates based on transparent legislation, and 4) The key to the success of Panwaslukada Gorontalo Regency in carrying out the duties and functions of the supervision, was more due to the active involvement of the community in responding to any violations in the stages of organizing the election of Regent and Vice Regent of Gorontalo Regency, so that the supervisors became cautious in carrying out duties with no impartial, honest, open and respond as soon as possible to every find and report of the community.

\section{ACKNOWLEDGMENT}

The writer would like to express their thanks to all parties, especially for the reviewer team who have provided valuable suggestion and guidance in writing this article

\section{REFERENCES}

[1] S. Malle dan J. Cooper, "The pendulum moves from Europe to Asia. Modernizing Siberia and the Far East. Economic and security issues," J. Eurasian Stud., vol. 5, no. 1, hal. 21-38, 2014.

[2] J. Everett, D. Neu, dan A. S. Rahaman, "Accounting and the global fight against corruption," Accounting, Organ. Soc., vol. 32, no. 6, hal. 513-542, 2007.

[3] H. Yee, "Analyzing the state-accounting profession dynamic: Some insights from the professionalization experience in China," Accounting, Organ. Soc., vol. 37, no. 6, hal. 426-444, 2012.

[4] N. Kshetri, "Success of Crowd-based Online Technology in Fundraising: An Institutional Perspective," J. Int. Manag., vol. 21, no. 2, hal. 100-116, 2015.

[5] M. Joy dan R. K. Vogel, “Toronto’s governance crisis: A global city under pressure," Cities, vol. 49, hal. 35-52, 2015.

[6] R. Vengroff, "Immigration Policy at the Subnational Level In North America: Quebec and Georgia In Comparative Perspective," Norteamérica, vol. 8, hal. 141-170, 2013.

[7] N. A. Phelps, T. Bunnell, M. A. Miller, dan J. Taylor, "Urban inter-referencing within and beyond a decentralized Indonesia," Cities, vol. 39, hal. 37-49, 2014.

[8] V. Tolz dan I. Busygina, "Regional governors and the Kremlin: the ongoing battle for power," Communist Post-Communist Stud., vol. 30, no. 4, hal. 401-426, 1997.

[9] S. Dewachter, N. Holvoet, M. Kuppens, dan N. Molenaers, "Beyond the Short versus Long Accountability Route Dichotomy: Using Multi-track Accountability Pathways to Study Performance of Rural Water Services in Uganda," World Dev., vol. 102, hal. 158-169, 2018.

[10] M. Dynel, "With or without intentions: Accountability and (un)intentional humour in film talk," J. Pragmat., vol. 95, hal. 67-78, 2016.

[11] A. Fournier, "Immature publics: Democratic revolutions and youth activists in the eye of authority," Anthropol. Q., vol. 88, no. 1, hal. 37-65, 2015.

[12] J. w. Creswell, Research Design: qualitative, quantitative, and Mix Methods Approaches, Fourth. Los Angeles, USA: Sage Publications, 2014.

[13] A. Rahmanurrasjid, "Akuntabilitas dan Transparansi Dalam Pertanggungjawaban Pemerintah Daerah untuk Mewujudkan Pemerintahan yang Baik di Daerah (Studi di Kabupaten Kebumen)." Program Pascasarjana Universitas Diponegoro, 2008.

[14] A. Ufen, "The legislative and presidential elections in Indonesia in 2009," Elect. Stud., vol. 29, no. 2, hal. 281-285, 2010. 